\title{
Which is the most appropriate parenting style for the adolescents' self-esteem among Acehnese people?
}

\author{
Izzatur Rusuli \\ Islamic Education Department, Postgraduate Studies of IAIN Takengon, Indonesia \\ Corresponding author: izzaturrusuli10@gmail.com
}

\section{ARTICLE INFO}

Article history

Received February 3, 2020

Revised November 16, 2020

Accepted November 26, 2020

Keywords

authoritarian style; authoritative style; permissive style; self-esteem; uninvolved style.

\begin{abstract}
Parenting is a process of how parents treat their children, and it has an essential role in the children's development comprehensively, including children's self-esteem. This research aimed to identify the parenting styles practiced by the Acehnese people, the level of adolescents' self-esteem in Aceh, and the correlation between four parenting styles and adolescents' self-esteem. A total of 368 junior high school students in Aceh participated in this research. The research instrument consisted of two questionnaires; to measure parenting styles and to measure adolescents' self-esteem. This study used Pearson correlation and ANOVA in data analysis. The results show that the authoritative style is the dominant parenting style applied in this study. Meanwhile, most of the adolescents' self-esteem levels are at a moderate level. The results also show that there is a significant correlation between the authoritative style and adolescents' self-esteem, as well as authoritarian style and permissive style, but the last two styles have a weak correlation. Meanwhile, there is no significant correlation between uninvolved style and adolescents' self-esteem. Based on the study results, it can be concluded that the optimum parenting style to develop self-esteem is the authoritative style among the four parenting styles.
\end{abstract}

\section{Introduction}

Adolescence is a period of transition from children to adults (Pertiwi \& Wardani, 2019). This period is known as a stormy period because adolescents have both internal and external problems. Internal problems are physical changes that occur due to the maturation of reproductive functions, making adolescents uncomfortable. Meanwhile, the external problem is the demand from their social environment, including their families, to act like adults while they are not mature. In these conditions, adolescents need self-esteem to recognize their existence by significant others around them.

An individual's assessment of himself where he is valuable, capable, and competent is called self-esteem (Alsheikh, Parameswaran, \& Elhoweris, 2010; Gecas \& Schwalbe, 1983). According to Coopersmith (1967), there are four aspects of self-esteem; power, significance, virtue, and competence. Power is the ability of an individual to influence others because of the person's recognition or respect for him. Meanwhile, the significance here means that the individual believes that he is significant, valuable according to the standard of individual assessment in his life and the environment around him. Therefore, his existence is considered or recognized by those around him. While virtue here means that an individual can adjust himself behaving in accordance with the norms, moral values, and religion. Competence means that an individual can achieve his goals or ideals. If the four aspects are high, then the 
individual has high self-esteem. On the other hand, if the four aspects are low, it can reduce self-esteem.

Adolescents who have high self-esteem cannot only face life's challenges but also get benefits for academic achievement (Adiputra, 2015). This is because adolescents who positively assess their abilities will try optimally to get the best results. Also, they have high motivation in the learning process. Moreover, adolescents who have high self-esteem will not commit suicide when they have problems in their lives (Pertiwi \& Wardani, 2019) and will refrain from engaging in drug activities (Trisakti \& Astuti, 2014).

Based on several previous studies, several factors influence adolescent self-esteem, such as experience, upbringing, environment, and family socioeconomic status (Budiman \& Rahmawati, 2011). Another study has found that the factors that most influence adolescent self-concept are peers, upbringing, physical appearance, and self-esteem (Saraswatia, Zulpahiyana, \& Arifah, 2015). Meanwhile, based on a literature review conducted by Gorrese \& Ruggieri (2013) shows that peer attachment, both globally and specifically, significantly affects individual self-esteem. Some of these studies indicate that parenting is one factor that influences adolescent self-esteem (Carolina \& Suradijono, 2019; Maria \& Novianti, 2017; Zakeri \& Karimpour, 2011).

Parenting is the parents' responsibility through interactions with the children related to improving, raising, guiding, and directing (Baumrind, 1991; Darling \& Steinberg, 1993; Maccoby \& Martin, 1983). Baumrind (1966, 1991) initiated parenting styles based on two main dimensions; responsiveness and demandingness. When these two dimensions are combined with different stresses, they will produce three different types of parenting. The three parenting styles are authoritative, authoritarian, and permissive. The authoritative style is characterized by parents who have high warmth and control (high responsiveness and demandingness). They are assertive but balanced with a willingness to hear children's opinions, warm, open, give children opportunities to develop by directing children rationally. In contrast, the authoritarian style is characterized by high control and low affection, very strict and rigid in making rules with their children. On the contrary, the permissive style is characterized by high warmth and love given to children but low control (Baumrind, 1966). However, Maccoby \& Martin (1983) added one type: neglect or uninvolved characterized by low responsiveness and demandingness, meaning that children are left alone. In general, the best parenting style is the authoritative style, where there is a balance between love and parental control so that it will have a positive influence on children's development, including children's self-esteem (Ezdha \& Sari, 2019; Maya, Soetjiningsih, \& Adnyana, 2018; Siregar \& Suci, 2011).

Research on the correlation between parenting style and children's self-esteem has mixed results. As research by Chan \& Koo (2010) on UK adolescents shows that parents who practice an authoritative style yield adolescents who have high self-esteem, good health, low interaction in smoking, fighting, and drugs. This research is in line with Trisakti \& Astuti (2014) and Yulia (2017) research. In contrast to the research of Martinez \& Garcia (2007), which shows that authoritative style is not always associated with high self-esteem for Brazilian adolescents, this is also in line with Zakeri \& Karimpour (2011) research. In their research, Martinez, Garcia, \& Yubero (2007) concluded that there is no difference between adolescents raised in an authoritative style and a permissive style regarding self-esteem and academic achievement. Meanwhile, in Spain, based on research by Martinez \& Garcia (2007), adolescents raised in a permissive style with high self-esteem compared to adolescents raised in an authoritative style, and adolescents raised in an authoritarian style have the worst scores of self-esteem. However, Garcia \& Gracia (2009) also found that parents who practice permissive and authoritative styles produce maximum adolescent development.

Meanwhile, in Indonesia, the results of Nancye \& Itayanti (2014) on Balinese adolescents show that children raised in a permissive style have low self-esteem, while children who have high self-esteem are mainly raised authoritarian style. According to the 
research conducted by Afriani, Baharudin, Siti-Nor, \& Nurdeg (2012) in Acehnese society, adolescents brought up in an authoritarian and permissive style have a high social responsibility compared to adolescents brought up in an authoritative style. This study is not in line with Alfiasari \& Wulandari (2011), which found authoritarian parenting reduces children's self-esteem. Meanwhile, Longkutoy, Sinolungan, \& Opod (2015) research shows that democratic (authoritative) parenting has a significant relationship with children's selfesteem.

Chao \& Tseng (2002) found that traditionally, the parenting style between father and mother is different for Chinese adolescents; fathers tend not to be close to the children but set rules for them. Meanwhile, mothers tend to be closer and give affection to their children. This parenting style has a significant relationship with children's self-esteem. But these findings are limited to non-immigrant Chinese parents. The same thing also happened in the research of Alsheikh et al. (2010) on Arab adolescents who stated that in their tradition, parents who have control tend to produce children who have good academic achievement, but there is no relationship between parenting style and self-esteem.

However, the research results on authoritarian style in Indonesia show individuals raised in an authoritarian style have a positive and significant relationship with bullying behavior both as perpetrators and victims Irmayanti (2016). Moreover can even reduce their self-esteem (Pratama, Krisnatuti, \& Hastuti, 2014). Also, the authoritarian style has a relationship with aggressive adolescent attitudes (Anggaraningtyas, Lilik, \& Nugroho, 2013), affect low self-esteem (Herlambang, Lilik, \& Agustin, 2013), and reduce social intelligence, academic achievement, and individual self-esteem (Alfiasari \& Wulandari, 2011).

Based on the exposure above, it is known that there are different results in research on parenting style. Generally, the authoritative style is the best parenting style and has a significant correlation with individual development. However, some studies show that authoritarian and permissive parenting does not always harm individual development. Viewing this statement, the researcher is interested in investigating the relationship between the four parenting styles as a whole with the adolescents' self-esteem in Aceh. This study's novelty is that the researcher is investigating the relationship between the four parenting styles and adolescent self-esteem. At the same time, the previous research only examined the relationship between one of the parenting styles and adolescent self-esteem. Moreover, this study also tries to find differences between the four parenting styles on adolescent selfesteem.

The participants in this study are Acehnese adolescents. Historically, the Acehnese people have experienced quite a long period of suffering, starting from colonialism against the Dutch then followed by conflict with the central government (Usman, 2003). The more tremendous devastating was the tsunami earthquake (Afriani et al., 2012; Vatikiotis, 2007). But they have a very close brotherhood bond and a persistent and strong trait that lead them to rise again (Hartini, 2010) to path their future. However, in the current era, the Acehnese's socio-cultural values are now starting to fade so that adolescents no longer care about the values (Puteh, 2012). Indeed, this life journey will affect the self-esteem of the next generation.

This study aims to explore the parenting styles applied in Aceh, the level of adolescent self-esteem in Aceh. This study also aims to find the correlation between authoritative styles with adolescent self-esteem, the correlation between authoritarian style with adolescent selfesteem, the correlation between permissive style with adolescent self-esteem, and the correlation between uninvolved style with adolescent self-esteem. Therefore, parents can provide the best upbringing for their children to grow and develop well, based on this study's result. 


\section{Method}

\section{Research Design}

This study is quantitative research using a survey method, a research method to find facts from symptoms and factual explanations and the relationship between variables of a group or region (Sugiyono, 2014).

\section{Participants}

As many as 368 Acehnese students aged 13-15 years in Lhokseumawe Aceh participated in this study. Participants consisted of 179 males and 189 females. The participants were mostly students in Grade 8 in junior high school. Based on age, participants were mostly 15 years old $(40.5 \%)$. Meanwhile, the participants' families were extended families with 3 to 4 children and 135 families (36.7\%). The average socioeconomic status of the participant's parents was medium (39.4\%). The participant's father and mother's educational background was mostly graduated from senior high school, respectively $45.6 \%$ and $42.4 \%$. Table 1 depicts the demography of the participants.

Table 1

Demography of Participant Characteristics

\begin{tabular}{|c|c|c|}
\hline Characteristics & (n) & Percentage $(\%)$ \\
\hline \multicolumn{3}{|l|}{ Gender } \\
\hline Male & 179 & 48.6 \\
\hline Female & 189 & 51.4 \\
\hline \multicolumn{3}{|l|}{ Age } \\
\hline 13 years old & 93 & 25.3 \\
\hline 14 years old & 126 & 34.2 \\
\hline 15 years old & 149 & 40.5 \\
\hline Family Size & & 13.6 \\
\hline 1 child & 50 & \\
\hline 1-2 children & 98 & 25.3 \\
\hline 3-4 children & 135 & 36.7 \\
\hline$>4$ children & 85 & 23.1 \\
\hline \multicolumn{3}{|l|}{ Socio-economic status } \\
\hline Low $(<600.000)$ & 125 & 34.0 \\
\hline Medium $(600.000<X<1.800 .000)$ & 145 & 39.4 \\
\hline High $(>1.800 .000)$ & 98 & 26.6 \\
\hline \multicolumn{3}{|l|}{ Father's education } \\
\hline Elementary School & 82 & 22.3 \\
\hline Junior High School & 77 & 20.9 \\
\hline Senior High School & 168 & 45.7 \\
\hline University & 41 & 11.1 \\
\hline \multicolumn{3}{|l|}{ Mother's education } \\
\hline Elementary School & 79 & 21.5 \\
\hline Junior High School & 86 & 23.3 \\
\hline Senior High School & 156 & 42.4 \\
\hline University & 47 & 12.8 \\
\hline
\end{tabular}

\section{Instruments}

A set of questionnaires was distributed to the students, which comprised the students' upbringing and self-esteem. To complete the questionnaire takes about 20-30 minutes. No 
participants were excluded from filling out the questionnaire because they had filled out all the items contained in the questionnaire.

The instrument for measuring parenting style is a combination of items in the Parental Authority Questionnaire (PAQ) developed by (Buri, 1991) and the items on the Parental Acceptance-Rejection Questionnaire (PARQ/Control) developed by Rohner (2005). PAQ consists of 30 items comprising ten items for authoritative, ten items for authoritarian, and ten items permissive. In contrast, PARQ consists of 9 items comprising uninvolved style. This combined instrument uses a Likert scale with 5 points ranging from $5=$ strongly agree to $1=$ strongly disagree. PAQ has a Cronbach alpha value for the authoritative style is .623 with a differentiating index of items ranging from .294 to .617. In this case, Sugiyono (2014) said that an instrument is stated reliable if the reliability coefficient is at least 0.6. Meanwhile, authoritarian style items have a Cronbach alpha value of .606 with an item differentiation index ranging from .319 to .609. The permissive style items have a Cronbach alpha value of .714 with an item differentiation index ranging from .296 to .696. And the items for uninvolved style also have a Cronbach alpha value .605 with an item differentiation index ranging from .329 to .594 . To identify the types of parenting perceived by participants is by viewing which parenting styles gain the highest score.

Meanwhile, the instrument to measure self-esteem used the Rosenberg Self-esteem Scale (RSES) created by Rosenberg (1965) to test global self-esteem. This RSES contains ten items consisting of five positive statements and five negative statements exerting a 4point Likert scale ranging from $4=$ strongly agree to $1=$ strongly disagree for positive items. The scores obtained will be reversed for negative items, where $1=$ strongly agree and $4=$ strongly disagree. Thus, the highest score obtained is 40. The coefficient of composite reliability of RSES is .608 , with an item difference index ranging from .437 to .807 . Table 2 shows the scale used in this study.

Table 2

\begin{tabular}{|c|c|c|c|c|}
\hline Scales & $\begin{array}{l}\text { Measurement } \\
\text { of }\end{array}$ & $\begin{array}{l}\text { Number } \\
\text { of items }\end{array}$ & $\begin{array}{l}\text { Cronbach's } \\
\text { alpha }\end{array}$ & Example of item \\
\hline \multirow[t]{3}{*}{ PAQ } & Authoritative & 10 & .623 & $\begin{array}{l}\text { As I was growing up, my parents gave me clear } \\
\text { direction for my behaviors and activities, but they } \\
\text { were also understanding when I disagree with them }\end{array}$ \\
\hline & Authoritarian & 10 & .606 & $\begin{array}{l}\text { My parents felt that wise parents should teach their } \\
\text { children early just who is boss in the family }\end{array}$ \\
\hline & Permissive & 10 & .716 & $\begin{array}{l}\text { As I was growing up, my parents allowed me to } \\
\text { decide most things for myself without a lot of } \\
\text { direction from them }\end{array}$ \\
\hline PARQ & Uninvolved & 9 & .605 & $\begin{array}{l}\text { As I was growing up, my parents didn't care to me if } \\
\text { I ask helping }\end{array}$ \\
\hline \multirow[t]{2}{*}{ RSES } & Positive & 5 & .608 & As a whole I am satisfied with myself \\
\hline & Negative & 5 & & Sometimes I think that I am not good in at all \\
\hline
\end{tabular}

\section{Data Analysis}

Descriptive statistical analysis was used to describe the participants' demographic data, including data on the parenting styles perceived by participants and their self-esteem. Meanwhile, Pearson analysis is used to test the hypothesis in this study. ANOVA analysis 
was also used to identify differences in participants' self-esteem based on the four parenting styles. Data were analyzed using the SPSS program Windows 17.

\section{Results}

The most parenting style perceived by adolescents is an authoritative style as many as 137 families $(37.3 \%)$. The second rank was the authoritarian style amounted to 98 parents $(26.6 \%)$. Meanwhile, 81 parents $(22.0 \%)$ practice the permissive style. The rest who practices uninvolved style is 52 families $(14.1 \%)$. The results of this study indicate that most parents in Lhokseumawe Aceh give high affection and control equally to their children. Only a small proportion does not care about their children. Table 3 describes the parenting styles practiced.

Table 3

\section{Distribution of Parenting Styles}

\begin{tabular}{lll}
\hline Parenting Style & Sample $(n)$ & Percentage $(\%)$ \\
\hline Authoritative & 137 & 37.3 \\
Authoritarian & 98 & 26.6 \\
Permissive & 81 & 22.0 \\
Uninvolved & 52 & 14.1 \\
\hline
\end{tabular}

The majority of participants, as many as 199 adolescents (54.1\%), have moderate selfesteem, and the rest, 167 adolescents $(45.4 \%)$, have high self-esteem. While only two teenagers $(0.5 \%)$ have low self-esteem, as shown in Table 4.

Table 4

Distribution of Adolescents' Self-esteem

\begin{tabular}{lcc}
\hline Level & Sample $(n)$ & Percentage $(\%)$ \\
\hline Low & 2 & 0.5 \\
Moderate & 199 & 54.1 \\
High & 167 & 45.4 \\
\hline
\end{tabular}

If elaborated more in detail about adolescents' self-esteem based on parenting style, then as in Table 5 below.

Table 5

Distribution of Adolescents' Self-esteem Based on Parenting Styles

\begin{tabular}{lllll}
\hline \multirow{2}{*}{ Parenting Style } & \multicolumn{2}{l}{ Level of Self-Esteem } & Total \\
\cline { 2 - 5 } & High & Moderate & Low & 137 \\
\hline Authoritative & 111 & 26 & 0 & 98 \\
Authoritarian & 29 & 69 & 0 & 81 \\
Permissive & 18 & 61 & 2 & 52 \\
Uninvolved & 9 & 43 & 0 & \\
\hline
\end{tabular}

Table 5 shows that most adolescents raised in an authoritative style have high selfesteem, as many as 111 adolescents, and the rest have moderate self-esteem. While the majority of adolescents raised in authoritarian style have moderate self-esteem, they are 69 adolescents, and 29 adolescents have high self-esteem. While adolescents raised with permissive style mostly have medium self-esteem, as many as 61 adolescents, only 18 adolescents have high self-esteem, and two adolescents with low self-esteem. Forty-three 
adolescents who are cared for with uninvolved style mostly have moderate self-esteem, and only nine adolescents have high self-esteem.

The analysis shows a significant correlation between authoritative style and adolescent self-esteem ( $r=.489, p=.000)$, indicates that adolescents who are nurtured in an authoritative style have high self-esteem. Pearson analysis also shows a significant correlation between authoritarian style and adolescent self-esteem $(r=.318, p=.001)$. This analysis also shows a significant correlation between the permissive style and adolescent self-esteem $(r=.339$, $p=.002)$. However, the uninvolved style does not significantly correlate with adolescent selfesteem ( $r=.063, p=.658)$. Table 6 shows the correlation between the variables.

Table 6

Correlation between Parenting Style with Adolescents' Self-esteem

\begin{tabular}{lll}
\hline Variables & $R$ & $p$ value \\
\hline Authoritative $(\mathrm{n}=137)$ & $.489^{*}$ & .000 \\
Authoritarian $(\mathrm{n}=98)$ & $.318^{*}$ & .001 \\
Permissive $(\mathrm{n}=81)$ & $.339^{*}$ & .002 \\
Uninvolved $(\mathrm{n}=52)$ & .063 & .658 \\
\hline
\end{tabular}

*significant $p<.05$

ANOVA analysis was applied to discern the differences in adolescent self-esteem based on the parenting styles. It showed that the F count value is 65.109 , with $p=.000$ ( $p<$. 05), indicating a significant difference in adolescent self-esteem in terms of parenting styles. Table 7 illustrates the different tests of self-esteem based on parenting styles.

Table 7

The Difference in Adolescents' Self-esteem Based on Parenting Styles

\begin{tabular}{lllrcrc}
\hline & Sum of Squares & \multicolumn{1}{c}{ df } & Mean Square & F & Sig. \\
\hline \multirow{2}{*}{ Self-esteem } & Between Groups & 2318.552 & 3 & 772.851 & 65.109 & .000 \\
& Within Groups & 4320.728 & 364 & 11.870 & & \\
& Total & 6639.280 & 367 & & & \\
\hline
\end{tabular}

The descriptive statistical analysis results showed that the empirical mean of adolescents' self-esteem raised in an authoritative style is the highest compared to other parenting styles $(\mathrm{M}=33.50, \mathrm{SD}=3.4, \mathrm{n}=137)$. The second highest empirical mean of adolescents' self-esteem is those who are raised with authoritarian parenting $(\mathrm{M}=28.91, \mathrm{SD}$ $=3.5, \mathrm{n}=98$ ). Meanwhile, the next empirical mean is adolescents nurtured with an uninvolved style $(\mathrm{M}=28.04, \mathrm{SD}=3.1, \mathrm{n}=52)$. And the lowest empirical mean is adolescents who are raised with a permissive style $(\mathrm{M}=27.90, \mathrm{SD}=3.6, \mathrm{n}=81)$.

\section{Discussion}

The main aim of this study is to address the correlation between parenting style with adolescents' self-esteem. Generally, it shows correlations between the three types of parenting with their children's self-esteem except for the style of uninvolved that does not have a significant correlation. The results of this study support the statement stated by Coopersmith (1967) and Zakeri \& Karimpour (2011) that one of the external factors influencing individual self-esteem is parenting style. Although Gorrese \& Ruggieri (2013) 
also concluded based on a literature review, the attachment to peers globally and specifically is an external factor that influences individual self-esteem.

This study shows that the more authoritative parents are in upbringing adolescents, the higher their self-esteem. Adolescents raised in an authoritative style mostly have high selfesteem. It is due to parents applying the authoritative style to provide attention, warmth, and openness and compensate by flexible control and willingness to listen to their adolescents' opinions (Baumrind, 1991). Therefore, adolescents feel valued because their existence is recognized and considered to have the competence or ability to do something, so they have high self-esteem. Adolescents who have high self-esteem have four aspects of self-esteem; power, value, competence, and virtue (Coopersmith, 1967), and these four aspects can be obtained through the authoritative style.

This study supports the previous studies that parents who practice an authoritative style will yield adolescent who has high self-esteem (such as Baumrind, 1991; Baumrind \& Black, 1967; Chan \& Koo, 2010; Lamborn, Mounts, Steinberg, \& Dornbusch, 1990; Radziszewska, et al., 1996; Steinberg, et al., 1994). This study also found most parents in Indonesia practice an authoritative style that has a positive influence on the adolescent's development, such as high self-esteem (Dewi, Suharso, \& Supriyo, 2013; Herlambang et al., 2013; Maya et al., 2018; Siregar \& Suci, 2011) not smoking and not consuming drugs (Trisakti \& Astuti, 2014) and has an excellent social (Yulia, 2017). However, this study's results are different from those of Afriani et al. (2012) on Acehnese adolescents who concluded that there is no significant correlation between authoritative style and social responsibility.

This study also finds that mostly Acehnese people practice authoritative style for upbringing their adolescent. These results differ from those of Chao \& Tseng (2002), who stated that Asia's best style is the authoritarian style. It seems that there has been a shift in socio-cultural values in Acehnese society as happened in Australia, where formerly, the upbringing practiced by the Australian people was an authoritarian style and now shifts to an authoritative style.

In Acehnese society, this change could have originated from a tsunami that had destroyed the joints of life in Aceh. Therefore, a lot of assistance comes from local organizations and abroad to help reorganize life in Aceh (Hartini, 2010; Vatikiotis, 2007). By their arrival directly or indirectly also influence the socio-cultural values adopted by the people of Aceh, including parenting.

The Acehnese people used to have strong identity values, so these identities and values have shifted and started to fade (Puteh, 2012) so that some of them do not practice what has been practiced by their ancestors included in parenting style. Parents had a rigid and strict parenting style in the past, but now there is no longer their assertiveness towards their children. However, the authoritative style is the best style offered by Baumrind because this style will have a positive influence on children's development. Thus, there is no problem in shifting values and parenting changes because of the change in a positive direction.

This study also shows a significant correlation between authoritarian style and adolescents' self-esteem, and this style occupies the second sequence after an authoritative style. However, most adolescents raised in an authoritarian style have moderate self-esteem as many as 69 adolescents, and the rest have high self-esteem as many as 29 teenagers. Participants of this study are a collectivist group who assume that the authoritarian style emphasizing the rules and controls is common. This parenting style is not considered a rejection by their children. Even parents giving strict discipline to their children are a form 
of their love and care (Chao \& Tseng, 2002), so the authoritarian style does not negatively affect their children's development. This result supports the part of the research of Afriani et al. (2012) and Panjaitan \& Daulay (2012), which states that adolescents who are raised with an authoritarian style can socialize well.

However, this study is contrary to Anggaraningtyas et al. (2013), which stated that adolescents who are raised in an authoritarian style are aggressive. Likewise, this study is not in line with the previous research that concluded that the authoritarian style contributes to self-esteem and leads to bullying behavior (Dalimunthe, Marjohan, \& Syahniar, 2014; Irmayanti, 2016; Maya et al., 2018; Pratama et al., 2014).

Meanwhile, this study finds a significant correlation between the permissive style and adolescents' self-esteem. Based on this study's results, adolescents who are raised with a permissive style mostly have moderate self-esteem. Adolescents raised in a permissive style gain more love or attention without any control that can make their existence recognized and do what they want. Consequently, this leads to an increase in their self-esteem. By recognition from others, adolescents will feel valued so that it has a positive impact on selfesteem. The study results are in line with the research of Martinez \& Garcia (2007) on Brazilian adolescents stated that parents who give love and apply dialogue in their care could foster children having high self-esteem. Martinez \& Garcia (2007) also found that Spanish adolescents nurtured in a permissive style have high self-esteem. The relationship between parents and children in Spain is egalitarian in which the children feel they have the same position as their parents so that they feel valued, and of course, this can enhance their selfesteem. This study also supports one of Alfiasari \& Wulandari (2011) that concluded a significant and positive correlation between the permissive style and children's self-esteem and academic achievement.

Meanwhile, the result of this study finds that there is no correlation between uninvolved style and adolescents' self-esteem. Due to adolescents who are raised in this pattern, they feel that they have the same abilities as other friends who are cared for in other styles so that the parents' neglect does not affect their self-esteem. The reason is Acehnese adolescents with any parenting style have no demands from their parents to master specific skills, so their abilities are the same, and this is what makes their self-esteem at a moderate level. That is why most adolescents who are raised in the uninvolved style have moderate self-esteem as well.

Furthermore, it is found that there are differences in adolescents' self-esteem in terms of the four parenting styles, so there is a significant difference between the four parenting styles. Moreover, the results of the descriptive statistics show that the authoritative style ranks the highest. This result shows that the authoritative style is the best parenting style in developing adolescents' self-esteem. Thus, this study supports previous research that states that authoritative parenting is an effective style in fostering children's personalities, including self-esteem. However, this study's results also indicate that authoritarian style can still be applied in parenting because this style has a significant relationship with self-esteem and ranks second. The Acehnese community's culture places parents as individuals who must be respected, obeyed, and listened to. The existence of firmness about parents' position in the children's eyes does not make them restrained or controlled. Still, it is regarded as positive, so that tight demandingness does not reduce their self-esteem.

This study's limitation is that the researcher investigates parenting styles by uniting the questionnaire for parenting of father and mother, which may be in one family, both parents 
have different styles. Besides, this study was only conducted on early adolescents who were in junior high schools in Aceh. It is suggested to other researchers to expand the number of participants and be executed on adolescents who were graded in senior high school to gain more powerful results.

\section{Conclusion}

Among the four parenting styles, the optimum parenting style is the authoritative style in which parents provide affection and give the demand in balance for their children. The authoritative style has a significant correlation with adolescent self-esteem, and they possess high self-esteem. Meanwhile, adolescents raised with authoritarian style (low affection but high demands) and permissive parenting (high affection but low demands) have moderate self-esteem, but the relationship level is weak. Likewise, adolescents raised in uninvolved styles also have moderate self-esteem, but there is no correlation. Therefore, it is recommended that parents always give love and rules balance in the family to yield high self-esteem. Future researchers suggest conducting the same research by separating the parenting style between father and mother and increasing the number of participants to obtain more accurate data.

\section{References}

Adiputra, S. (2015). Keterkaitan self efficacy dan self esteem terhadap prestasi belajar mahasiswa (The relationship between self efficacy and self esteem with undergraduate students' learning achievement). Jurnal Fokus Konseling, 1(2), 151-161.

Afriani, A., Baharudin, R., Siti-Nor, Y., \& Nurdeg, D. (2012). The relationship between parenting style and social responsibility of adolescents in Banda Aceh, Indonesia. Pertanika Journal Social Science and Humanities, 20(3), 733-750.

Alfiasari, L. M., \& Wulandari, A. (2011). Pengasuhan otoriter berpotensi menurunkan kecerdasan sosial, self-esteem, dan prestasi akademik remaja (Authoritarian parenting has the potential to reduce social intelligence, self-esteem, and academic achievement of adolescents). Jurnal Ilmu Keluarga Dan Konsumen, 4(1), 46-56. https://doi.org/10.24156/jikk.2011.4.1.46

Alsheikh, N., Parameswaran, G., \& Elhoweris, H. (2010). Parenting style, self-esteem and student performance in the United Arab Emirates. Current Issues in Education, 13(1), $1-24$.

Anggaraningtyas, Y., Lilik, S., \& Nugroho, A. A. (2013). Hubungan antara koping stres dan persepsi pola asuh otoriter dengan kecenderungan perilaku agresi pada remaja yang dimoderasi oleh konformitas teman sebaya pada siswa kelas XI SMK Muhammadiyah 4 Boyolali (The relationship between stress coping and perceptions of authoritarian parenting with a tendency to aggressive behavior in adolescents moderated by peer conformity among grade XI students of SMK Muhammadiyah 4 Boyolali). Jurnal Ilmiah Psikologi Candrajiwa, 1(4), 1-10.

Baumrind, D. (1966). Effect of authoritative parental control on child behavior. Child Developmental Psychology, 37(4), 887-907. https://doi.org/10.2307/1126611

Baumrind, D. (1991). The influence of parenting style on adolescent competence and substance use. Journal of Early Adolescence, 11(1), 56-95. https://doi.org/10.1177\%2F0272431691111004 
Baumrind, D., \& Black, A. E. (1967). Socialization practices associated with dimensions of competence in preschool boys and girls. Child Development, 38(2), 291-327. https://psycnet.apa.org/doi/10.2307/1127295

Budiman, Juhaeriah, J., \& Rahmawati, F. (2011). Faktor-faktor yang mempengaruhi harga diri remaja akhir (16-18 tahun) akibat perceraian orang tua di SMA Negeri 3 Subang (Factors that affect the self-esteem of late adolescents (16-18 years) due to the divorce of parents at SMA Negeri 3 Subang). Proceeding Industrial Research Workshop and National Seminar, 2, 1-5.

Buri, J. R. (1991). Parental authority questionnaire. Journal of Personality Assessment, 57(1), 110-119. https://doi.org/10.1207/s15327752jpa5701_13

Carolina, S., \& Suradijono, S. H. R. (2019). Parental belief dan self-esteem anak: Studi pada budaya Betawi (Parental belief and child self-esteem: Study on Betawi culture). Provitae: Jurnal Psikologi Pendidikan, 12(1), 19-28. https://doi.org/10.24912/provitae.v12il.5052

Chan, T. W., \& Koo, A. (2010). Parenting style and youth outcomes in the UK. European Sociological Review, 27(3), 385-399. https://doi.org/10.1093/esr/jcq013

Chao, R. K., \& Tseng, V. (2002). Parenting of asians. In M. H. Bornstein (Ed.), Handbook of Parenting (pp. 59-94). Lawrence Erlbaum Associates.

Coopersmith, S. (1967). The antecedents of self esteem. W.H. Freeman and Company.

Dalimunthe, R., Marjohan, \& Syahniar. (2014). Kontribusi pengasuhan orangtua dan selfesteem terhadap perilaku bullying (Contribution of parental parenting and self-esteem to bullying behavior). Konselor, 3(4), 1-7.

Darling, N., \& Steinberg, L. (1993). Parenting style as context: An integrative model. Psychological Bulletin, 113(3), 487-496. https://psycnet.apa.org/doi/10.1037/00332909.113.3.487

Dewi, D. M., Suharso, \& Supriyo. (2013). Kepercayaan diri ditinjau dari pola asuh orang tua pada siswa kelas VII (Studi Kasus) (Self-confidence and parenting style among seventh grade students (a case study)). Indonesia Journal of Guidance and Counseling: Theory and Application, 2(4), 9-16.

Ezdha, A. U. A., \& Sari, W. A. (2019). Hubungan antara pola asuh orang tua dengan self esteem anak usia prasekolah di TK Negeri Pembina lll Pekanbaru (The relationship between parenting style and self-esteem of preschool children on TK Negeri Pembina III Pekanbaru). Jurnal Ilmu Keperawatan, 8(2), 42-51.

Garcia, F., \& Gracia, E. (2009). Is always authoritative the optimum parenting style? Evidence from spanish families. Adolescence, 44(173), 101-131.

Gecas, V., \& Schwalbe, M. L. (1983). Beyond the looking-glass self: Social structure and efficacy-based self-esteem. Social Psychology Quarterly, 46(2), 77-88. https://psycnet.apa.org/doi/10.2307/3033844

Gorrese, A., \& Ruggieri, R. (2013). Peer attachment and self-esteem: A meta-analytic review. Personality and Individual Differences, 55(5), 559-568. https://doi.org/10.1016/j.paid.2013.04.025

Hartini, N. (2010). Bencana tsunami dan stres pasca trauma pada anak (Tsunami disaster and post traumatic stress in children). Jurnal Masyarakat Kebudayaan Dan Politik, 22(3), 259-264.

Herlambang, A. S. U., Lilik, S., \& Agustin, R. W. (2013). Perbedaan kepercayaan diri pada siswa dengan perilaku bermasalah ditinjau dari pola asuh orang tua di SMAN 1 Kauman Tulungagung (Differences in self-confidence in students with problematic behavior in terms of parenting styles in SMAN 1 Kauman Tulungagung). Jurnal Ilmiah Psikologi Candrajiwa, 2(1), 1-9. 
Irmayanti, N. (2016). Pola asuh otoriter, self esteem dan perilaku bullying ( Authoritarian parenting, self-esteem and bullying behavior). Jurnal Penelitian Psikologi, 07(01), 2035 .

Lamborn, S. D., Mounts, N. S., Steinberg, L., \& Dornbusch, S. (1990). Patterns of competence and adjustment among adolescents from authoritative, authoritarian, indulgent, and neglectful families. Child Development, 62(5), 1049-1065. https://doi.org/10.2307/1131151

Longkutoy, N., Sinolungan, J., \& Opod, H. (2015). Hubungan pola asuh orang tua dengan kepercayaan diri siswa SMP Kristen Ranotongkor Kabupaten Minahasa (The relationship between parenting style and students' self-confidence in SMP Kristen Ranotongkor Kabupaten Minahasa). Jurnal E-Biomedik (EBm), 3(1), 93-99. https://doi.org/10.35790/ebm.3.1.2015.6612

Maccoby, E. E., \& Martin, J. A. (1983). Socialization in the context of the family: Parentchild interaction. In E. M. Hetherington \& P. . (General E. Mussen (Eds.). Handbook of Child Psychology Vol. 4: Socialization personality and social development (4th ed.). John Wiley \& Sons.

Maria, I., \& Novianti, R. (2017). Pengaruh pola asuh dan bullying terhadap harga diri pada anak kelompok B TK di Kota Pekanbaru Tahun 2016 (The effect of parenting and bullying on self-esteem in children grade B kindergarten in Pekanbaru city at 2016). Educhild, 6(1), 61-69.

Martinez, I., \& Garcia, J. F. (2007). Impact of parenting styles on adolescents' self-esteem and internalization of values in Spain. The Spanish Jurnal of Psychology, 10(2), 338348. https://doi.org/10.1017/S1138741600006600

Martinez, I., Garcia, J. F., \& Yubero, S. (2007). Parenting styles and adolescents' self-esteem in brazil. Psychological Reports, 100(3), 731-745.

Maya, S., Soetjiningsih, W. I. T., \& Adnyana, I. S. (2018). Korelasi pola asuh orangtua terhadap self-esteem remaja Sekolah Lanjutan Tingkat Pertama Harapan Denpasar (Correlation of parenting style to adolescent self-esteem in Harapan Secondary School Denpasar). Sari Pediatri, 20(1), 24-30. https://dx.doi.org/10.14238/sp20.1.2018.24-30

Nancye, M. P., \& Itayanti. (2014). Hubungan pola asuh orang tua dengan harga diri remaja di Banjar Pengenderan Kedonganan-Kuta (The relationship between parenting style and youth self-esteem in Banjar Pengenderan Kedonganan- Kuta). Jurnal Keperawatan, 3(2).

Panjaitan, D. S., \& Daulay, W. (2012). Pola asuh orang tua dan perkembangan sosialisasi remaja di SMA Negeri 15 Medan (Parenting patterns and the development of adolescent socialization in SMA Negeri 15 Medan). Jurnal Keperawatan Holistik, 1(1).

Pertiwi, N. F., \& Wardani, I. Y. (2019). Harga diri remaja dan pola asuh orangtua sebagai faktor protektif ide bunuh diri (Adolescent self-esteem and parenting styles as protective factors for suicidal ideation). Jurnal Ilmiah Permas: Jurnal Ilmiah STIKES Kendal, 9(3), 301-310. https://doi.org/10.32583/pskm.9.3.2019.301-310

Pratama, A. A., Krisnatuti, D., \& Hastuti, D. (2014). Gaya pengasuhan otoriter dan perilaku bullying di sekolah menurunkan self-esteem anak usia sekolah (Authoritarian parenting style and bullying behavior at school reduce the self-esteem of school age children). Jurnal Ilmu Keluarga Dan Konseling, 7(2), 75-82. https://doi.org/10.24156/jikk.2014.7.2.75

Puteh, M. J. (2012). Sistem-sosial budaya dan adat masyarakat Aceh (The socio-cultural and customary systems of the Acehnese people). Grafindo Litera Media.

Radziszewska, Barbara, Richardson, J. L., Dent, C. W., \& Flay, B. R. (1996). Parenting style and adolescent depressive symptoms, smoking, and academic achievement: Ethnic, 
gender, and SES differences. Journal of Behavioral Medicine, 19(3), 289-305. https://doi.org/10/1007/BF01857770

Rohner, R. (2005). Parental acceptance-rejection questionnaire (PARQ): Test manual. In V. Zeigler-Hill \& T. K. Shackelford (Eds.). Handbook for the study of parental acceptance and rejection (pp. 443-106). https://doi.org/10.1007/978-3-319-28099-8_56-1

Rosenberg, M. (1965). Soceity and the adolescent self-image. University Press.

Saraswatia, G. K., Zulpahiyana, \& Arifah, S. (2015). Faktor-faktor yang mempengaruhi konsep diri remaja di SMPN 13 Yogyakarta (Factors that influence adolescent selfconcept in SMPN 13 Yogyakarta). Journal Ners Dan Kebidanan Indonesia, 3(1), 3338. https://dx.doi.org/10.21927/jnki.2015.3(1).33-38

Siregar, N. S. A., \& Suci, D. H. (2011). Hubungan inteligensi dan pola asuh orangtua demokratis dengan harga diri siswa (The relationship between intelligence and democratic parenting with students' self-esteem). Jurnal Analitika, III(2), 66-71.

Steinberg, L., Lamborn, S. D., Darling, N., Mounts, N. S., \& Dornbusch, S. M. (1994). Overtime changes in adjustment and competence among adolescents from authoritative, authoritarian, indulgent, and neglectful families. Child Development, 65(3), 754-770. https://doi.org/10.2307/1131416

Sugiyono. (2014). Metode Penelitian Kombinasi (Mixed Methods) (5th ed.). Alfabeta.

Trisakti, \& Astuti, K. (2014). Hubungan antara harga diri dan persepsi pola asuh orang tua yang authoritatif dengan sikap remaja terhadap penyalahgunaan narkoba (The relationship between self-esteem and perceptions of authoritative parenting with adolescent attitudes towards drug abuse). Jurnal Ilmiah Guru “COPE, ” XVIII(02), 2431.

Usman, A. R. (2003). Sejarah peradaban Aceh: Suatu analisis interaksionis integrasi dan konflik (History of Aceh civilization: An integration and conflict interactionist analysis). First Edition. Yayasan Obor Indonesia.

Vatikiotis, M. (2007). Civil war, conflicts, and natural disasters. In A. Ananta \& L. P. Onn (Eds.). Aceh a New Dawn (pp. 7-13). ISEAS Publishing.

Yulia, P. S. (2017). Hubungan persepsi terhadap pola asuh orangtua dan harga diri dengan penyesuaian sosial siswa kelas x SMK Strada Budi Luhur Bekasi (The relationship between perceptions of parenting and self-esteem with social adjustment among grade X students of SMK Strada Budi Luhur Bekasi). Jurnal Psiko-Edukasi, 15, 56-66.

Zakeri, H., \& Karimpour, M. (2011). Parenting styles and self-esteem. Procedia - Social and Behavioral Sciences, 29, 758-761. https://doi.org/10.1016/j.sbspro.2011.11.302 